\title{
Peningkatan Keterampilan Membuat Alat Peraga Matematika Pada Mahasiswa Prodi PGSD Universitas Peradaban
}

\author{
Adi Candra Kusuma *1, Anggraeni Mashinta Sulistyani ${ }^{2}$, Eka Trisnawati ${ }^{3}$ \\ ${ }^{1}$ Program Studi Teknik Komputer, Politeknik Harapan Bersama \\ 2Program Studi PGSD, STKIP Majenang \\ 3Program Studi Farmasi, Fakultas Sains dan Teknologi, Universitas Peradaban \\ *e-mail: candraraden45@gmail.com ${ }^{1}$, amashintas@gmail.com ${ }^{2}$, eka.psnbio@gmail.com ${ }^{3}$
}

\begin{abstract}
In understanding abstract mathematical concepts, students need teaching aids such as concrete objects as an intermediary or visualization. The purpose of the research is to obtain skills in making mathematics teaching aids on PGSD University of Civilization students. The research method uses qualitative research with a total of 66 research subjects in the third semester of 2015/2016 Academic Year. Data collection techniques were taken using observation, interviews, documentation. The results obtained from the study provide knowledge of new knowledge, improve skills in making learning support instruments, train the creative thinking of students of the University of Civilization PGSD as a provision of learning strategies when going to be a teacher. This training prepares prospective teachers in explaining mathematical concepts, in learning mathematics, the use of teaching aids is expected to increase student motivation. Motivation can arise because many ideas and new ideas and fun learning contains a variety of information that is relevant to the learning needs of students.
\end{abstract}

Keywords: teaching aids, skills, mathematics

\begin{abstract}
Abstrak
Dalam memahami konsep matematika yang abstrak, siswa memerlukan alat peraga seperti bendabenda konkrit sebagai perantara atau visualisasinya Tujuan dari penelitian memperoleh keterampilan dalam membuat alat peraga matematika pada mahasiswa PGSD Universitas Peradaban. Metode penelitian menggunakan penelitian kualitatif dengan subjek penelitian sejumlah 66 mahasiswa semester III Tahun Akademik 2015/2016. Teknik pengumpulan data yang diambil menggunakan observasi, wawancara, dokumentasi. Hasil penelitian diperoleh dari penelitian memberikan pengetahuan ilmu baru, meningkatkan ketrampilan dalam membuat instrumen penunjang pembelajaran, melatih pemikiran kreatif mahasiswa PGSD Universitas Peradaban sebagai bekal strategi pembelajaran ketika akan menjadi guru. Pelatihan ini menyiapkan calon guru dalam menjelaskan konsep matematika, dalam pembelajaran matematika, penggunaan alat peraga diharapkan dapat meningkatkan motivasi belajar siswa. Motivasi bisa timbul karena banyak gagasan dan ide-ide baru dan pembelajaran yang menyenangkan tersebut mengandung berbagai informasi yang relevan dengan kebutuhan belajar siswa.
\end{abstract}

Kata Kunci: alat peraga, Keterampilan, matematika

\section{PENDAHULUAN}

Penanaman bekal pengetahuan dasar matematika siswa pada jenjang pendidikan dasar memegang peran penting dalam usaha meningkatkan kualitas sumber daya manusia di masa yang akan datang (Murdiana, 2010). Bidang studi matematika merupakan salah satu yang menduduki peranan penting dalam dunia pendidikan dapat dilihat dengan diajarkan di institusiinstitusi pendidikan, baik ditingkat SD, SMP, SMA hingga perguruan tinggi. Namun kebanyakan siswa merasa kesulitan dalam mempelajari matematika. Salah satu faktor yang membantu memudahkan siswa dalam memahami konsep matematika adalah guru, dimana guru matematika yangbaik adalah guru yang mampu mengatasi dan menyelesaikan masalah pembelajaran di dalam kelas secara bijaksana.

Berdasarkan hasil observasi di beberapa Sekolah dasar (SD) lingkungan Kecamatan Bumiayu Kabupaten Brebes, pada pembelajaran matematika guru dihadapkan pada kondisi 
pembelajaran yang kurang kondusif untuk dapat meningkatkan hasil belajar yang diharapkan kondisi tersebut disebabkan karena matematika yang obyek pemecahannya abstrak dipelajari siswa sekolah dasar yang tingkat berfikirnya konkrit seperti pada penelitian Dahniar dkk menjelaskan bagaimanapenggunaan alat perega dapat meningkatkan hasil belajar siswa kelas 1 SD Negeri6 Tolitoli dalam menyelesaikan soal cerita tenteng penjumlahan dan pengurangan dengan hasil penelitian Bahwa dengan meningkatnya hasil belajar siswa tersebut, berarti pembelajaran dengan menggunakan alat peraga terbukti dapat meningkatkan hasil belajar siswa dalam menyelesaikan soal cerita (Murdiana, 2010).

Pembelajaran adalah sebuah aktifitas yang dirancang oleh guru dalam membantu siswa untuk belajar sesuai dengan kemampuannya dengan sistematis melalui perencanaan, aksi dan evaluasi (Ishak, 2020).Permasalahan lainnya terdapat pada guru. Kebanyakan guru dalam mengajar di kelas masih kurang memperhatikan kemampuan berpikir siswa, media yang digunakan kurang bervariasi, dan sebagai akibatnya motivasi belajar siswa menjadi sulit ditumbuhkan dan pola belajar cenderung menghafal dan mekanistis. Ditambah lagi dengan penggunaan pendekatan pembelajaran yang cenderung membuat siswa pasif dalam proses belajar- mengajar, yang membuat siswa tidak tertarik untuk mengikuti pelajaran. Oleh karena itu, dibutuhkan ketekunan, keuletan, perhatian, dan motivasi yang tinggi dari guru untuk membantu siswa dalam memahami materi yang diajarkan pada pembelajaran matematika.

Universitas Peradaban merupakan salah satu perguruan tinggi swasta yang terletak di Jalan Raya Pagojengan KM 3, Kecamatan Paguyangan Kabupaten Brebes. Kampus ini memiliki 4 Fakultas diantaranya Fakultas Keguruan dan Ilmu Pendidikan (FKIP) terdapat jurusan PGSD. Kampus ini mempunyai harapan dapat mencetak lulusan calon guru yang kompeten dan kreatif dibidangnya. Salah satu yang harus bisa dikuasai oleh mahasiswa ini sebagai calon guru adalah mampu membuat instrumen pendukung pembelajaran diantaranya adalah alat peraga. Mahasiswa PGSD di Universitas Peradaban cukup banyak yang sudah memiliki profesi guru SD (kuliah sembari bekerja), untuk menunjang SDM mereka diharuskan memiliki ijazah lulusan PGSD. Bahwasanya yang harus diketahui sebagai calon guru PGSD, Salah satu tugas guru/pendidik adalah merencanakan kegiatan pembelajaran matematika, melaksanakan kegiatan pembelajaran matematika sampai menilai hasil belajar siswa.

Kajian yang abstrak atau objek dari matematika adalah benda-benda yang sifatnya abstrak. Dapat diartikan bahwa objek matematika tidak mudah diamati dan dipahami dengan panca indera. Dengan demikian tidak mengherankan jika matematika tidak mudah dipahami oleh sebagian siswa khususnya siswa SD/MI karena taraf berfikir anak SD/MI masih pada tahap konkret seperti yang diungkapkan oleh Piaget (Gunung \& Kecamatan, 2019).

Dari hal itu, salah satu tugas pendidik yaitu merencanakan kegiatan pembelajaran matematika, melaksanakan kegiatan pembelajaran matematika serta menilai hasil

belajar siswa. Guru mendesain kegiatan pembelajaran yang akan dilaksanakan dalam kelas akan diawali dengan membuat Rencana Pelaksanaan Pembelajaran (RPP) yang didalamnya termuat aspek-aspek diantaranya merumuskan tujuan pembelajaran, memilih materi ajar (sesuai tujuan dan karakteristik siswa), mengorganisasi materi ajar (keruntutan, sistematika materi dan kesesuaian dengan alokasi waktu), memilih sumber/media pembelajaran, menyusun scenario pembelajaran (kegiatan awal, inti, akhir) (Widyantini, Si, Tg, Si, \& Nasional, 2010). Matematika bersifat abstrak sehingga untuk mempelajari objek matematika yang abstrak diperlukan jembatan atau perantara yang bersifat konkret untuk mengurangi keabstrakan tersebut dengan menggunakan model-model benda-benda konkret. Model benda nyata yang digunakan untuk mengurangi keabstrakan materi matematika tersebut dinamakan alat peraga pembelajaran matematika.

Istilah alat peraga sering menggatikan istilah media pembelajaran. Alat peraga matematika dapat diartikan sebagai suatu perangkat benda konkrit yang dirancang, dibuat, dan disusun secara sengaja yang digunakan untuk membantu menanamkan dan memahami konsepkonsep atau prinsip-prinsip dalam matematika (Annisah, 2014) . 
Menurut Estiningsih, alat peraga merupakan media pembelajaran yang mengandung atau membawakan ciri-ciri dari konsep yang dipelajari. Alat peraga adalah suatu benda asli dan benda tiruan yang digunakan dalam proses belajar mengajar yang menjadi dasar bagi tumbuhnya konsep berpikir abstrak bagi peserta didik (Kunci, n.d.).

Selain itu yang paling penting adalah kedudukan alat peraga terkait dengan fungsi pedagogik yang merupakan salah satu upaya untuk mempertinggi proses interaksi guru dengan siswa di lingkungan belajarnya. Melalui alat peraga siswa dapat berperan aktif dalam pembelajaran. Proses interaksi akan terjalin antara siswa dengan guru dan juga antara siswa dengan siswa ketika mereka belajar dengan menggunakan alat peraga (Pendidikan \& Pontianak, 2019)

\section{METODE}

Jenis penitian yang digunakan penelitian kualitatif dengan subyek penelitian 66 mahasiswa semester 3 PGSD Universitas Peradaban Tahun Akademik 2015/2016. Metode pengumpulan data menggunakan observasi, wawancara dan dokumentasi. Instrument penelitian yang disiapkan yaitu pedoman wawancara, lembar observasi, lembar kerja kegiatan pembuatan alat peraga.

Mahasiswa dikelompokan menjadi 7 kelompok dengan masing-masing terdiri dari 7-8 mahasiswa. Pembagian kelompok dengan membagi mahasiswa yang mempunyai kecerdasan dan kedisiplinan secara merata berdasarkan wawancara dan hasil nilai IPK mahasiswa. Pemberian pelatihan membuat alat peraga terdiri dari 3 kegiatan yaitu pemberian materi, pembuatan alat peraga dan presentasi hasil alat peraga. Pelatihan dilakukan selamat 3 hari mulai 1-3 Oktober 2015 bertempat di Ruang Kelas 2.2 Kampus Universitas Peradaban dan di luar ruangan.

Lembar observasi berisi hasil pengamatan dan pencatatan yang sistematis terhadap gejala-gejala yang diteliti ketika penelitian berlangsung. Ada beberapa hal yang diamati dalam pengumpulan data pada lembar observasi yaitu: perencanaan ide pembuatan alat peraga, kesesuaian dengan silabus (materi). Pedoman Wawancara dilakukan terhadap guru SD, siswa dan mahasiswa PGSD. Wawancara terhadap guru dilakukan agar dapat diketahui sejauh mana kendala/saran yang dihadapi peneliti dalam proses pembelajaran matematika. Metode dokumentasi penelitian ini digunakan untuk memperoleh data-data tertulis tentang daftar nama mahasiswa, jumlah mahasiswa dan data lain yang mendukung terlaksananya penelitian pembuatan alat peraga ini.

Lembar kerja pembuatan alat peraga terdiri dari unsur yaitu nama kelompok, materi, tujuan pembelajaran alat dan bahan, langkah-langkah pembuatan, hambatan pembuatan produk, dokumentasi kegiatan dan produk.

\section{HASIL DAN PEMBAHASAN}

Kegiatan dilaksanakan pada 1 - 3 Oktober 2015 yang diikuti oleh 66 mahasiswa prodi PGSD bertempat di Ruang Kelas 2.2 Kampus Universitas Peradaban dan di luar ruangan.

Peserta pelatihan diberikan materi mengenai pentingnya alat peraga sebagai penunjang pembelajaran matematika untuk siswa. Pemberian materi ini yang memberikan gambaran bahwa sebagai calon pendidik harus memahami/ respek terhadap kondisi siswa khususnya kesulitan atau kendala yang sering dijumpai mereka, sehingga perlu adanya suatu pengetahuan keterampilan mengenai alat peraga yang dimana untuk membantu menanamkan dan mengembangkan konsep matematika. Pemberian materi dilakukan secara berkelompok dimaksudkan untuk meningkatkan komunikasi peserta. Pelatihan pembuatan alat peraga matematika merupakan hal baru bagi mahasiswa PGSD Universitas Peradaban, berdasarkan wawancara, tanya jawab dan pengamatan langsung terhadap peserta terlihat sangat antusias mengikuti pelatihan seperti Nampak pada Gambar 1. 


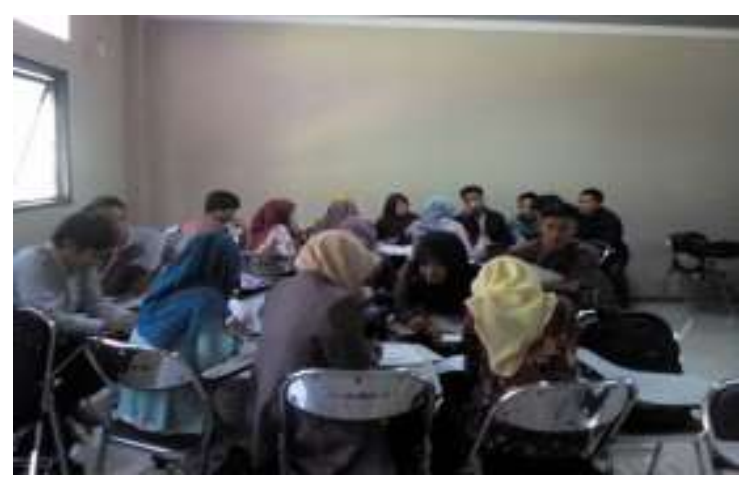

Gambar 1. Pemberian Materi Pelatihan

Matematika merupakan suatu ilmu yang berhubungan dengan penelaahan bentuk-bentuk suatu struktur yang abstrak dan hubungannya. Untuk dapat memahaminya, diperlukan pemahaman tentang konsep-konsep yang terdapat dalam Matematika. Karena sifatnya yang abstrak, maka dalam pembelajaran matematika masih diperlukan benda-benda yang menjadi perantara atau alat peraga yang berfungsi untuk membantu mengkonkritkan sehingga faktafaktanya lebih jelas dan lebih mudah diterima oleh siswa. Oleh karena itu wajar apabila matematika tidak mudah dipahami oleh kebanyakan siswa usia sekolah dasar. Hal ini berdampak pada hasil belajar mahasiswa, perubahan perilaku yang harus dicapai siswa setelah melakukan aktivitas belajar dirumuskan dalam tujuan pembelajaran. Menurut Anni et. al (2005) hasil belajar mencakup tiga ranah, yaitu: kognitif, afektif, dan psikomotorik (Setyowati, Susilo, \& Masrukan, 2016). Dalam memahami suatu konsep matematika, siswa masih harus diberikan rangkaian kegiatan nyata yang dapat diterima akal mereka. Dengan demikian alat bantu belajar atau biasa disebut media sangatlah diperlukan dalam pembelajaran matematika, untuk memberikan pengalaman belajar yang bermakna, mengaktifkan dan menyenangkan. Setelah pemberian materi peserta dibagi menjadi 9 kelompok dengan masing-masing terdiri dari 7 - 8 mahasiswa.

Alasan perlunya dibuat kelompok dalam pelatihan ini karena Salah satu model pembelajaran yang dapat mengaktifkan peserta adalah model "Cooperatif Learning" (pembelajaran kooperatif). Pembelajaran kooperatif adalah metode pembelajaran berkelompok, sehingga dapat mengaktifkan peserta sebab dalam kelompok mereka diharapkan dapat bekerja sama dan berdiskusi menyelesaikan tugas-tugas yang diberikan guru/pemateri (Yensy, 2012). Adapun pembagian kelompok akan diberikan tugas membuat satu alat peraga. Daftar alat peraga yang akan dibuat ada pada tabel 1.

Tabel 1 daftar alat peraga

\begin{tabular}{ll}
\hline \multicolumn{1}{c}{ Kelompok } & \multicolumn{1}{c}{ Alat peraga } \\
\hline Kelompok 1 & Papan berpaku \\
Kelompok 2 & Timbangan bilangan \\
Kelompok 3 & Saringan Erastotenes \\
Kelompok 4 & Dekak dekak \\
Kelompok 5 & Papan simetri putar \\
Kelompok 6 & Labirin Manis BilanganBulat \\
Kelompok 7 & Blok pecahan \\
Kelompok 8 & Dakon KPK dan FPB \\
Kelompok 9 & Muka jam \\
\hline
\end{tabular}

Setiap benda yang ada dihadirkan dalam pelajaran belum dapat dikatakan alat peraga, sebab mungkin saja benda itu hanya alat penyampaian ataupun alat pelajaran saja. Fungsi utama alat peraga adalah menurunkan keabstrakan konsep agar siswa mampu menangkap arti konsep tersebut (Rusmawati, 2017). 
Kegiatan pembuatan alat peraga matematika mahasiswa diberikan lembar kerja (LK) untuk dilakukan pengisian dengan diskusi terhadap kelompoknya. Peserta diberikan waktu untuk berdiskusi mengisi LK dengan didampingi TIM.

Adanya alat peraga dalam pembelajaran matematika berfungsi sebagai : 1) Motivasi dalam proses belajar mengajar, khususnya bagi peserta didik akan dapat timbul minat belajar sehingga tercapainya tujuan belajar 2) Konsep abstrak matematika tersajikan dalam bentuk konkrit sehingga lebih mudah untuk dipahami dan dimengerti serta dapat ditanamkan pada tingkat yang lebih rendah 3) Hubungan antara konsep abstrak matematika dengan bendabenda di alam sekitar akan lebih dapat dipahami dengan jelas 4) Konsep-konsep abstrak yang disajikan dalam bentuk konkrit yaitu dalam bentuk model matematika yang dapat dipakai sebagai objek penelitian maupun sebagai alat untuk meneliti ide-ide baru dan relasi baru (Nasaruddin, 2018).

Pada proses pembuatan alat dan bahan disiapkan. Kegiatan pelatihan dilakukan oleh Tim yang dibantu mahasiswa dalam persiapan sampai pelaksanaan selesai. Contoh persiapan pembuatan alat peraga labirin manis bilangan bulat pada gambar 2

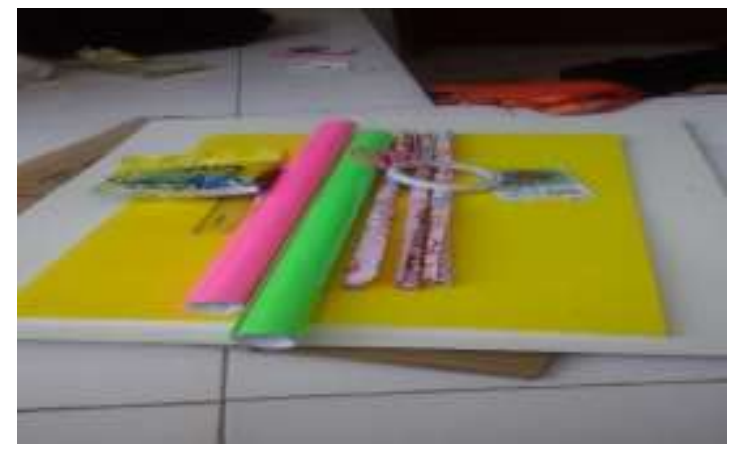

Gambar 2. Persiapan alat dan bahan

Pembuatan alat peraga timbangan bilangan Nampak pada gambar 3.

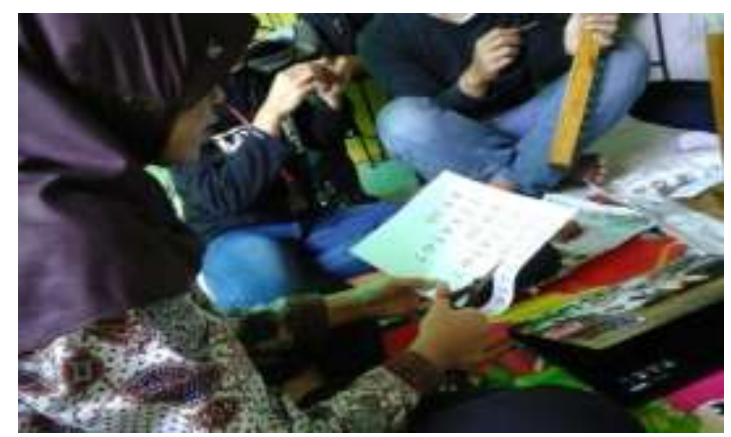

Gambar 3. Pembuatan Alat peraga matematika.

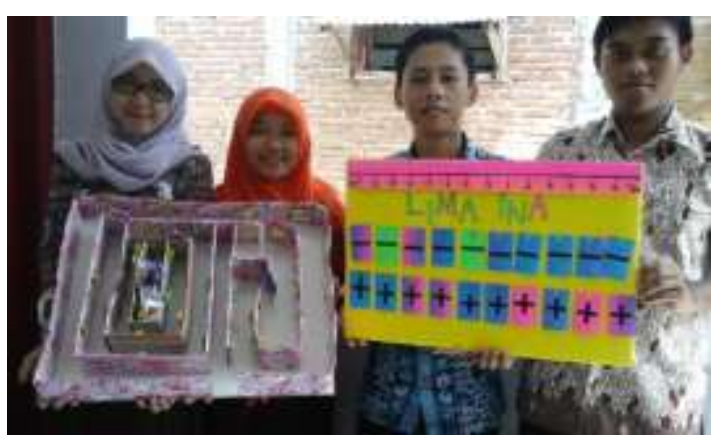

Gambar 4. Produk Pembuatan Alat peraga matematika yang sudah jadi. 
Kegiatan presentasi kelompok, masing-masing kelompok menjelaskan mulai dari persiapan sampai dengan pelaksanaa pembuatan alat peraga.

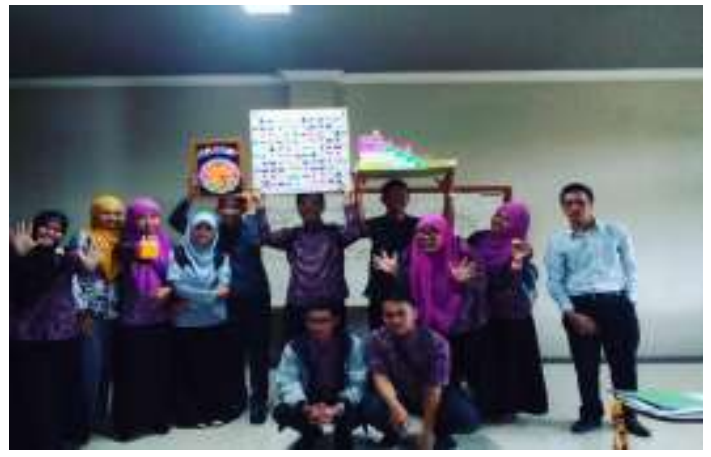

Gambar 5. Hasil Presentasi Produk Alat Peraga

Kendala yang dihadapi mahasiswa dalam pelatihan ini yaitu pemahaman konsep materi dengan tujuan pembelajaran yang akan dicapai, kemudian disaat pembuatan alat peraga khususnya pada pembuatan alat peraga yang sifatnya pengukuran harus teliti agar menghasilkan ketepatan angka yangh sesuai.

Dalam suatu proses pembelajaran, dua unsur yang amat penting adalah metode mengajar dan media pembelajaran. Kedua aspek ini saling berkaitan. Pemilihan salah satu metode mengajar tertentu akan mempengaruhi jenis media pembelajaran yang sesuai, meskipun masih ada berbagai aspek lain yang harus diperhatikan dalam memilih media, antara lain tujuan pembelajaran, jenis tugas dan respon yang diharapkan siswa kuasai setelah pembelajaran berlangsung, dan konteks pembelajaran termasuk karakteristik siswa. Meskipun demikian, dapat dikatakan bahwa salah satu fungsi utama media pembelajaran adalah sebagai alat bantu mengajar yang turut mempengaruhi iklim, kondisi, dan lingkungan belajar yang ditata dan diciptakan oleh tenaga pendidik.

Guru dapat menciptakan berbagai situasi kelas, menentukan metode pengajaran yang akan dipakai dalam situasi yang berlainan dan menciptakan iklim emosional diantara siswa. Bahkan alat/media pembelajaran ini selanjutnya dapat membantu guru membawa dunia luar ke dalam kelas. Dengan demikian ide yang abstrak diharapkan dapat dimengeri oleh siswa dan berpengaruh terhadap pencapaian tujuan pendidika. Maka dari itu sebagai calon guru sangat perlu menambah wawasan dan mengembangkan kreativitas dalam pengembangan maupun pemenfaatan media pembelajaran. Sebelum itu, sebagai guru maupun calon guru harus mengetahui kelebihan diri sendiri, sehingga kita dapat memanfaatkan kelebihan terrsebut untuk menciptakan keunikan atau ciri khas pribadi sehingga kita sebagai guru mudah diingat oleh siswa, sebab hal tersebut bisa jadi dapat menarik minat peserta didik untuk bersemangat mengikuti pelajaran oleh guru yang bersangkutan. Seorang guru haruslah kreatif, untuk meningkatkan kreativitas kita perlu melatih, mengembangkan dan menemukan hal yang menonjol dari diri kita sebagai seorang guru. Maka dari untuk meningkatkan kemampuan sangat diperlukan mengikuti seminar maupun pelatihan yang mengarah langsung kepada pengembangan dan pemanfaatan media agar kita sebagai guru memiliki kualitas dengan cara mampu memanfaatkan media yang ada sehingga dapat dengan mudah kita lakukan pendekatan kepada siswa agar ia antusias mengikuti pelajaran yang kita berikan.

Pada prinsipnya penggunaan alat peraga dalam proses pembelajaran akan membantu kelancaran, efektivitas dan efisiensi pencapaian tujuan. Alat peraga dapat meningkatkan proses belajar siswa yang pada akhirnya diharapkan dapat meningkatkan hasil belajar siswa sesuai penelitian (Gunung \& Kecamatan, 2019). Menyadari pentingnya alat peraga dalam meningkatkan mutu keberhasilan proses pembelajaran, guru dituntut untuk menguasai keterampilan pengembangan dan kegunaan alat peraga serta keterampilan memilih alat peraga yang sesuai dengan konsep yang akan diajarkan. 
Beberapa hal yang menjadi faktor pendukung pada kegiatan pelatihan ini adalah a) Peserta kegiatan sangat antusias/ motivasi mengikuti kegiatan ini sampai selesai, b) Peserta mempunyai rasa keingintahuan tinggi terhadap materi ini, c) Peserta mau diberikan arahan dan bimbingan saat pelatihan.

Beberapa hal yang menjadi faktor penghambat pada kegiatan pelatihan ini adalah a) Waktu kurang memadai, karena pelatihan sangat singkat dengan materi yang cukup padat sehingga pekerjaan produk dibuat dilanjutkan dirumah. b) Menentukan waktu pelaksanaan pelatihan pembuatan buku ajar dikarenakan berbenturan dengan waktu aktif kuliah mahasiswa. c) Perlu ada workshop sehingga dapat memberikan pengetahuan lebih jauh tentang buku ajar pembelajaran. d) Peserta yang cukup banyak, membuat keadaan cukup berisikPengabdian kepada masyarakat adalah usaha untuk menyebarluaskan ilmu pengetahuan, teknologi, dan seni kepada masyarakat. Kegiatan tersebut harus mampu memberikan suatu nilai tambah bagi masyarakat, baik dalam kegiatan ekonomi, kebijakan, dan perubahan perilaku (sosial). Uraikan bahwa kegiatan pengabdian telah mampu memberi perubahan bagi individu/masyarakat maupun institusi baik jangka pendek maupun jangka panjang.

\section{KESIMPULAN}

Pelatihan peningkatan pembuatan alat peraga pada mahasiswa prodi PGSD Universitas Peradaban berjalan dengan baik. Dari kegiatani diperoleh a) Alat peraga matematika dapat diartikan sebagai suatu perangkat benda konkrit yang dirancang, dibuat, dan disusun secara sengaja yang digunakan untuk membantu menanamkan dan memahami konsep-konsep atau prinsip-prinsip dalam matematika, b) Pengetahuan dan pemahaman mahasiswa PGSD Universitas Peradaban perkembangan mengenai intrumen penunjang pembelajaran (buku ajar) lebih baik, c) Keingintahuan mahasiswa akan pembuatan alat peraga matematika bertambah dan mendapatkan respon yang baik dalam mendengarkan pemaparan materi yang disampaikan. Mengingat besarnya manfaat kegiatan pengabdian masyarkat ini, maka selanjutnya perlu: a) Adanya pelatihan yang berkelanjutan, sehingga dapat dibuat alat peraga variasi yang lain, b) Waktu pelatihan diperpanjang sehingga mahasiswa lebih banyak mendapatkan materi tentang pembuatan alat peraga. c) Pendampingan perlu dilakukan selama pelatihan dan penggunaan alat peraga, d) Materi alat peraga yang dibuat lebih banyak lagi bahasan yang dikaji.

\section{DAFTAR PUSTAKA}

Annisah, S. (2014). Siti Annisah. 11, 1-15.

Gunung, S. D. N., \& Kecamatan, K. (2019). 56/ Dewantara Vol. VII, Januari-Juni 2019 p-ISSN: 2527$399 X \mid e-I S S N$ : 2541-609X. VII, 56-72.

Ishak, I. (2020). Pelatihan Guru Sd Di Tangerang: Implementasi Tpr Dalam Meningkatkan Penguasaan Bahasa Inggris. Dinamisia : Jurnal Pengabdian Kepada Masyarakat, 4(1), 1-5. https://doi.org/10.31849/dinamisia.v4i1.3659

Kunci, K. (n.d.). Media dan Alat Peraga Dalam Pembelajaran Matematika Oleh: Nasaruddin. 2130.

Murdiana, I. N. (2010). Penggunaan Alat Peraga Untuk Meningkatkan Hasil Belajar Siwa Kelas 1 SD Negeri 6 Tolitoli dalam Menyelesaikan Soal Cerita Tentang Penjumlahan Dan Pengurangan. 4(3), 165-177.

Nasaruddin, N. (2018). Media Dan Alat Peraga Dalam Pembelajaran Matematika. Al-Khwarizmi: Jurnal Pendidikan Matematika Dan Ilmu Pengetahuan Alam, 3(2), 21-30. https://doi.org/10.24256/jpmipa.v3i2.232

Pendidikan, F., \& Pontianak, I. P. (2019). Available online at: http://journal.uny.ac.id/index.php/jpmmp.3(1), 43-47.

Rusmawati. (2017). Penggunaan Alat Peraga Langsung pada Pembelajaran Matematika dengan Materi Pecahan Sederhana untuk Meningkatkan Hasil Belajar Siswa. Jurnal Ilmu Pendidikan 
Sosial, Sains, Dan Humaniora, 3(2), 307-314. Retrieved from http://103.193.19.206/index.php/suaraguru/article/view/3607/2128

Setyowati, N., Susilo, B. E., \& Masrukan, M. (2016). Penggunaan Alat Peraga untuk Meningkatkan Hasil Belajar dan Keaktifan Siswa Mata Diklat Matematika Materi Peluang Di Kelas X AP B Semester 2 SMK N 1 Bawen. Kreano, Jurnal Matematika Kreatif-Inovatif, 7(1), 24-30. https://doi.org/10.15294/kreano.v7i1.4831

Widyantini, D. R. A. T. H., Si, M., Tg, S., Si, M., \& Nasional, D. P. (2010). Pemanfaatan.

Yensy, N. (2012). Penerapan Model Pembelajaran Kooperatif Tipe Examples Non Examples Dengan Menggunakan Alat Peraga Untuk Meningkatkan Hasil Belajar Siswa Di Kelas Viii Smp N 1 Argamakmur. Exacta, 10(1), 24-35. 